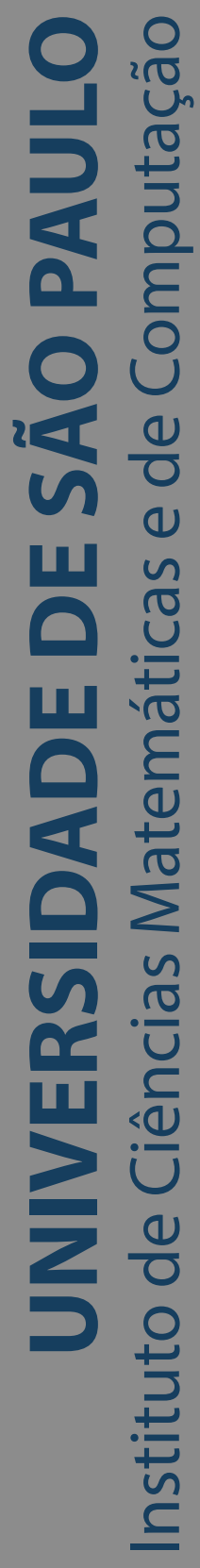

MaSTA: a text-based machine learning approach for systems-of-systems in the big data context

\title{
Thiago Bianchi
}

Tese de Doutorado do Programa de Pós-Graduação em Ciências de Computação e Matemática Computacional (PPG-CCMC) 

Assinatura:

\section{Thiago Bianchi}

\section{MaSTA: a text-based machine learning approach for systems-of-systems in the big data context}

Doctoral dissertation submitted to the Institute of Mathematics and Computer Sciences - ICMC-USP, in accordance with the requirements of the Computer Science and Computational Mathematics Program, for de degree of Doctor in Science. EXAMINATION BOARD PRESENTATION COPY

Concentration Area: Computer Science and Computational Mathematics

Advisor: Prof. Dr. Elisa Yumi Nakagawa 
Ficha catalográfica elaborada pela Biblioteca Prof. Achille Bassi e Seção Técnica de Informática, ICMC/USP, com os dados inseridos pelo(a) autor(a)

B577mchi, Thiago MaSTA: a text-based machine learning approach for systems-of-systems in the big data context / Thiago Bianchi; orientador Elisa Yumi Nakagawa. - são Carlos, 2019.

$211 \mathrm{p}$.

Tese (Doutorado - Programa de Pós-Graduação em Matemática) - - Instituto de Ciências Matemáticas e de Computação, Universidade de São Paulo, 2019.

1. System-of-Systems. 2. Big Data. 3. Text Classification. 4. Naive Bayes. 5. Machine Learning. I. Nakagawa, Elisa Yumi, orient. II. Título. 


\title{
Thiago Bianchi
}

\section{MaSTA: uma abordagem de aprendizado de máquina orientado a textos para sistemas-de-sistemas no contexto de big data}

\author{
Tese apresentada ao Instituto de Ciências \\ Matemáticas e de Computação - ICMC-USP, \\ como parte dos requisitos para obtenção do título \\ de Doutor em Ciências - Ciências de Computação \\ e Matemática Computacional. EXEMPLAR DE \\ DEFESA
}

Área de Concentração: Ciências de Computação e Matemática Computacional

Orientador: Prof. Dr. Elisa Yumi Nakagawa

USP - São Carlos

Fevereiro de 2019 

To the love of my life Talita and our son Henrique 

This thesis is the result of many years of work. Through the years, many people contributed, directly and indirectly, for achieving this result.

To God, to give me wisdom and guide my path.

To my wife, Talita Bianchi, for everything. Thank you for your affection, encouragement, and companionship. I am grateful to God for our marriage and for the blessing of having you by my side.

To my son Henrique, you are the joy of mommy and daddy.

To my parents, Lucas and Mary Bianchi. You gave me love, affection and invested in my education. I share with you the success of this work.

To my brother, Lucas, and his wife, Caroline, for the encouragement in the most difficult moments.

To my uncles, Silas and Rosa Bianchi, for the example of academic life and the incentive to complete this work.

To my advisor and friend Prof. Dr. Elisa Yumi Nakagawa, for friendship, companionship and valuable advice. We have known each other for a long time and I hope we will continue to work together.

To my friend Prof. Dr. Rodrigo Fernandes de Mello, for the precious contributions for this work.

To my friends Marcos and Cristiane Siqueira, Tabajara and Luciana Soares, Héber and Isabel Tscherne, and Benvindo and Maressa Pereira, for the brotherhood in Christ.

To my friends Fernando and Débora Paulovich, and Davi and Débora Diniz, although you are now distant, you participated in this journey.

To all my professors, fellow researchers, and students from the University of São Paulo, in particular to Daniel, Brauner, Milena, Lina, and Cristiane, whose friendship was a bonus during this journey.

To my friends with whom I worked together in IBM Brazil Software Lab. In particular, I would like to thank Marlon Vicente, Thiago Iunes, João Maior, Vinícius Garmatz, Milton Vieira, Rafael Davoli, Alessandra Lima, Daniel Lutz, and Leonardo Alvino, for the fellowship and exchange of knowledge. Besides them, I would also like to thank Gabriela Martins, Ana Brambilla, Alexis Silva, Joseph Schipper, Tiago Scarton, and Russell Bee for contributing to the initial stages of this research.

To my managers Eduardo Felício and Fernando Giglio. Thank you for your support.

To Dr. Dr. John Donald Vasquez (yes, he has two Ph.D.'s) and Dr. John Maxwell Cohn for inspiring me to continue pursuing the growth on the technical career at IBM. 

"The fear of the Lord is the beginning of knowledge, but fools despise wisdom and instruction." (Proverbs 1:7) 



\section{RESUMO}

BIANCHI, T. MaSTA: uma abordagem de aprendizado de máquina orientado a textos para sistemas-de-sistemas no contexto de big data. 2019. 211 p. Tese (Doutorado em Ciências - Ciências de Computação e Matemática Computacional) - Instituto de Ciências Matemáticas e de Computação, Universidade de São Paulo, São Carlos - SP, 2019.

Sistemas-de-sistemas ( $\mathrm{SoS}$ ) conquistaram um status muito importante na indústria e na academia como uma resposta à crescente complexidade dos sistemas intensivos de software. SoS são particulares no sentido de que suas capacidades transcendem a mera soma das capacidades de seus diversos constituintes independentes. Paralelamente, o crescimento atual na quantidade de dados coletados em diferentes formatos é impressionante e impõe um desafio considerável para pesquisadores e profissionais, caracterizando consequentemente o contexto de Big Data. Nesse cenário, técnicas de Aprendizado de Máquina têm sido cada vez mais exploradas para analisar e extrair conhecimento relevante de tais dados. SoS também têm gerado uma grande quantidade de dados e informações de texto e, em muitas situações, os usuários do SoS precisam registrar manualmente textos críticos não estruturados, por exemplo, ordens de serviço e solicitações de serviço, e também precisam mapeá-los para informações estruturadas. Além disso, essas tarefas são repetitivas, demoradas, e até mesmo propensas a erros. O principal objetivo desta Tese é apresentar o MaSTA, uma abordagem composta por um método de classificação inovador para inferir classificadores a partir de grandes coleções de texto e um método de avaliação que mensura os níveis de confiabilidade e desempenho desses classificadores. Para avaliar a eficácia do MaSTA, nós conduzimos um experimento com um SoS comercial utilizado por grandes empresas que nos forneceram quatro conjuntos de dados contendo quase um milhão de registros relacionados com três tarefas de classificação. Como resultado, esse experimento indicou que o MaSTA é capaz de classificar automaticamente os documentos e também melhorar a assertividade do usuário através da redução da lista de possíveis classificações. Além disso, esse experimento indicou que o MaSTA é uma solução escalável para os cenários de Big Data, nos quais as coleções de documentos têm centenas de milhares (até milhões) de documentos, até mesmo produzidos por diferentes constituintes de um SoS.

Palavras-chave: Sistema-de-Sistemas, Big Data, Classificação de Texto, Naive Bayes, Aprendizado de Máquina. 



\section{ABSTRACT}

BIANCHI, T. MaSTA: a text-based machine learning approach for systems-of-systems in the big data context. 2019. 211 p. Tese (Doutorado em Ciências - Ciências de Computação e Matemática Computacional) - Instituto de Ciências Matemáticas e de Computação, Universidade de São Paulo, São Carlos - SP, 2019.

Systems-of-systems ( $\mathrm{SoS}$ ) have gained a very important status in industry and academia as an answer to the growing complexity of software-intensive systems. SoS are particular in the sense that their capabilities transcend the mere sum of the capacities of their diverse independent constituents. In parallel, the current growth in the amount of data collected in different formats is impressive and imposes a considerable challenge for researchers and professionals, characterizing hence the Big Data context. In this scenario, Machine Learning techniques have been increasingly explored to analyze and extract relevant knowledge from such data. SoS have also generated a large amount of data and text information and, in many situations, users of SoS need to manually register unstructured, critical texts, e.g., work orders and service requests, and also need to map them to structured information. Besides that, these are repetitive, time-/effort-consuming, and even error-prone tasks. The main objective of this Thesis is to present MaSTA, an approach composed of an innovative classification method to infer classifiers from large textual collections and an evaluation method that measures the reliability and performance levels of such classifiers. To evaluate the effectiveness of MaSTA, we conducted an experiment with a commercial SoS used by large companies that provided us four datasets containing near one million records related with three classification tasks. As a result, this experiment indicated that MaSTA is capable of automatically classifying the documents and also improve the user assertiveness by reducing the list of possible classifications. Moreover, this experiment indicated that MaSTA is a scalable solution for the Big Data scenarios in which document collections have hundreds of thousands (even millions) of documents, even produced by different constituents of an SoS.

Keywords: System-of-Systems, Big Data, Text Classification, Naive Bayes, Machine Learning. 